\title{
EXPRESSION OF TISSUE-TYPE TRANSGLUTAMINASE CORRELATES POSITIVELY WITH METASTATIC PROPERTIES OF HUMAN MELANOMA CELL LINES
}

\author{
Jan J.M. van Groningen, Steve L. Klink, Henri P.J. Bloemers and Guido W.M. Swart ${ }^{1}$ \\ Department of Biochemistry, University of Nijmegen, Nijmegen, The Netherlands.
}

\begin{abstract}
In this study the relationship between tissue-type transglutaminase (TGase2) activity and the propensity to metastasize was investigated in human melanoma cell lines with different metastatic behavior. TGase2 catalyzes an acyl-transfer reaction between peptide-bound glutamine residues and primary amines, including the 6-amino group of lysine residues. Northern-blot analysis demonstrated that TGase2 RNA-expression (3.7 kb) was elevated in highly metastatic cell lines (MV3 and BLM) as compared to weakly metastatic ones (IF6 and 530). Immunoprecipitation and enzyme assays of TGase2 showed that the differential expression at the mRNA level was also reflected at the protein level. These findings reveal a positive relation between the expression of TGase 2 and the metastatic properties of the human melanoma cell lines.

(1) 1995 Wiley-Liss, Inc
\end{abstract}

Modifications of proteins commonly serve special purposes, e.g. they can modulate the activity of signal transduction cascades, determine protein fate, and stabilize intra- and extracellular matrices. Calcium-dependent acyl transferases, also known as transglutaminases (TGases), form one group of enzymes involved in these processes. TGases (EC 2.3.2.13) catalyse an acyl transfer reaction between peptide-bound glutamine residues and primary amine groups. As a result, substrate proteins incorporate amines (such as polyamines), or are cross-linked via $\epsilon(\gamma$-glutamyl)lysine bridges if the amine is a peptide-bound lysine (Folk and Finlayson, 1977).

In mammals, 5 distinct TGases have been described. TGase 1 is a particulate or membrane-associated activity of about 90 $\mathrm{kDa}$, originally discovered in epidermal keratinocytes (Thacher and Rice, 1985) and now known to be widely expressed (Kim et al., 1992); T'Gase 2 is a ubiquitous soluble or tissue-type activity of about $80 \mathrm{kDa}$, which is widely distributed in human cells and tissues (Gentile et al., 1991); TGase3, known as the epidermal or hair follicle TGase, is a soluble pro-enzyme activity of about $77 \mathrm{kDa}$ (Kim et al., 1991); furthermore, an inactive TGase-like protein of about $75 \mathrm{kDa}$ exists, which is a ubiquitous constituent of the plasma membrane of most eukaryotic cells (Sung et al., 1990), and the $77-\mathrm{kDa}$ catalytic subunit of blood-clotting factor XIII also has TGase activity (Ichinose et al., 1986). TGase2, by far the most abundant of these enzymes, has been implicated in the activation of receptor-mediated endocytosis (Davies et al., 1980), hormone secretion (Bungay et al., 1986), cell adhesion by cross-linking of extracellular proteins (Gentile et al., 1992; Martinez et al., 1989), and the formation of the apoptic envelope in cells undergoing programmed cell death (Fesus et al., 1987; Alaoui et al., 1992).

The present study was undertaken to examine the TGase2 activity in human melanoma cell lines with differing metastatic potential. Whereas reports on mouse melanoma cell lines (Beninati et al., 1993), hamster fibrosarcoma (Knight et al., 1990), and rat hepatocellular carcinoma (Hand et al., 1988) suggested that decreased levels of TGase 2 activity are associated with increased metastatic potential, our investigations on human melanoma cell lines show that TGase 2 expression correlates positively with the gain of metastatic properties.

\section{MATERIAL AND METHODS}

\section{Material}

All radiolabeled chemicals and Hybond $\mathrm{N}$-plus membranes were from Amersham (Den Bosch, The Netherlands). Kodak X-Omat AR5 films (Rochester, NY) were used for autoradiography. Purified guinea-pig tissue TGase was supplied by Sigma (Brussels, Belgium). Cell culture media and FCS were obtained from GIBCO (Grand Island, NY). All other reagents were of analytical grade.

\section{Melanoma cell lines and xenografts}

Human melanoma cell lines MV3, BLM, 530 and 1F6 (van Muijen et al., 1991 $a, b$ ) were grown as monolayers on Dulbecco's modified Eagle's medium supplemented with $10 \%$ FCS, glutamine $(2 \mathrm{mM})$, penicillin $\mathrm{G}$ (100 units $/ \mathrm{ml})$, streptomycin $(100 \mu \mathrm{g} / \mathrm{ml})$ and pyruvate $(1 \mathrm{mM})$. Cells were harvested by trypsinization. Xenograft tumors from nude mice were obtained as described (van Muijen et al., 1991a, b). Within the panel of human melanoma cell lines, 1F6 and 530 represent the non-metastatic or weakly metastatic cell lines, with a metastasis frequency of less than $10 \%$. The highly metastatic cell lines BLM and MV3 disseminate with a frequency of 50 and $90 \%$, respectively.

\section{$R N A$ isolation and Northern-blot analysis}

Total RNA was isolated using the lithium-urea procedure described by Auffray and Rougeon (1980). Between 10 and 20 $\mu \mathrm{g}$ of total RNA were glyoxylated (McMaster and Carmichael, 1977), size-fractionated on $1 \%$ agarose gels and blotted to Hybond $\mathrm{N}^{+}$membranes (Amersham, Aylesbury, UK). Hybridizations were performed according to Church and Gilbert (1984); the RNA was hybridized overnight in $0.5 \mathrm{M} \mathrm{Na}_{2} \mathrm{HPO}_{4}$ $\mathrm{pH} 7.2,1 \%$ BSA, $7 \%$ SDS, $1 \mathrm{mM}$ EDTA and $0.1 \mathrm{mg} / \mathrm{ml}$ denatured herring sperm DNA at $65^{\circ} \mathrm{C}$ with ${ }^{32} \mathrm{P}$-labeled DNA probes to a maximum of $1 \times 10^{6} \mathrm{cpm} / \mathrm{ml}$. Filters were washed at $65^{\circ} \mathrm{C}$ in $0.1 \mathrm{M} \mathrm{Na}_{2} \mathrm{HPO}_{4}$, pH 7.2, $0.5 \%$ SDS, 1 mM EDTA.

\section{DNA probes}

The human TGase 2 cDNA, a 3.5-kb EcoR1 fragment, was a generous gift from Dr. P. Davies, Houston, TX (Gentile et al., 1991). A 28S ribosomal probe was used to reconfirm equal loading of RNA samples in each lane. Probes were radiolabeled by nick-translation.

\section{Cytoplasmic extract preparation}

Cells were resuspended in $5 \mathrm{ml}$ lysis buffer $(10 \mathrm{mM}$ Tris$\mathrm{HCl}, \mathrm{pH} 8.0,1.5 \mathrm{mM} \mathrm{MgCl}, 0.5 \mathrm{mM}$ dithiothreitol, $0.1 \mathrm{mM}$ EDTA, $1 \mathrm{mM}$ phenylmethylsulfonyl fluoride, $1 \%$ trasylol) and lysed by 7 strokes in a Dounce homogenizer. Nuclei were removed by centrifugation at $1,000 \mathrm{~g}$ for $15 \mathrm{~min}$. Supernatant was concentrated by $75 \%\left(\mathrm{NH}_{4}\right)_{2} \mathrm{SO}_{4}$-precipitation followed by centrifugation at $150,000 \mathrm{~g}$ for $20 \mathrm{~min}$. The pellet containing

${ }^{1}$ To whom correspondence and reprint requests should be sent, at the Dept. of Biochemistry, Science Faculty, University of Nijmegen, P.O. Box 9101, 6500 HB Nijmegen. The Netherlands. Fax: 003180 540525 .

Received: June 29, 1994 and in revised form October 8, 1994. 
the TGase 2 protein was resuspended in, and dialyzed against, $50 \mathrm{mM}$ Tris- $\mathrm{HCl}, \mathrm{pH} 8.0,100 \mathrm{mM} \mathrm{NaCl}$. The protein concentration was determined by the Coomassie brilliant blue binding method (Bradford, 1976).

\section{Enzyme assays}

The enzymatic incorporation of $\left[{ }^{14} \mathrm{C}\right]$ methylamine into endogenous substrate was used to assay TGase activity (Lorand et al., 1981). The incubation mixture contained $50 \mathrm{mM}$ Tris$\mathrm{HCl}, \mathrm{pH} 8.0,100 \mathrm{mM} \mathrm{NaCl}, 10 \mathrm{mM} \mathrm{CaCl}, 10 \mathrm{mM}$ dithiothreitol, $0.4 \mathrm{mM}\left[{ }^{14} \mathrm{C}\right]$ methylamine with specific activity 56 $\mathrm{mCi} / \mathrm{mmol}$ and $0.3 \mathrm{mg}$ cytoplasmic protein extract in a final volume of $50 \mu \mathrm{l}$. After $60 \mathrm{~min}$ incubation at $37^{\circ} \mathrm{C}, 10-\mu \mathrm{l}$ aliquots of the incubation mixture were spotted onto Whatman $3 \mathrm{MM}$ filter paper. Free $\left[{ }^{14} \mathrm{C}\right]$ methylamine was eliminated by washing with excess of ice-cold 5\% TCA. Filters were dried and counted after addition of $5 \mathrm{ml}$ Aqualuma Plus (LUMAC LSC, Groningen, The Netherlands) in a Beckman model 2800 liquid scintillation counter.

For identification of the TGase substrate(s), $5 \mu \mathrm{l}(30 \mu \mathrm{g})$ of the incubation mixture were analyzed on $12.5 \%$ SDSpolyacrylamide gel. The gel was fluorographed, dried and exposed.

\section{Cell labelling and immunoprecipitation}

Cell labelling and isolation of proteins were based on the method described by Banks-Schlegel and Harris (1983). For labelling, the cells were plated in dishes $10 \mathrm{~cm}$ in diameter and grown until $50 \%$ confluent. Cells were washed twice with PBS and incubated for $30 \mathrm{~min}$ with $4 \mathrm{ml}$ of methionine-free Eaglc's minimal essential medium, to which were added $40 \mu \mathrm{Ci}$ $\left[{ }^{35}\right.$ S]methionine $(>1000 \mathrm{Ci} / \mathrm{mmol})$ and dialyzed $\mathrm{FCS}$ at a final concentration of $6 \%$. After overnight incubation at $37^{\circ} \mathrm{C}$, the cells were washed 3 times with PBS. The labelled cell pellet was lysed in $75 \mu \mathrm{l}$ of lysis buffer $(20 \mathrm{mM}$ Tris- $\mathrm{HCl}, \mathrm{pH} \mathrm{7.7,1}$ $\mathrm{mM}$ phenylmethylsulfonyl fluoride, $2 \%$ SDS, $10 \mathrm{mM}$ dithiothreitol). The lysates were boiled and centrifuged to eliminate insoluble materials. The supernatant was diluted in $1.425 \mathrm{ml}$ of RIPA buffer without SDS (RIPA buffer: $50 \mathrm{mM}$ Tris- $\mathrm{HCl}, \mathrm{pH}$ $7.5,0.15 \mathrm{M} \mathrm{NaCl}, 1 \%$ Triton $\mathrm{X}-100,1 \%$ sodium deoxycholate, $0.1 \%$ SDS, $0.5 \%$ Trasylol), and centrifuged. The resulting supernatant was used for immunoprecipitation. Aliquots containing $2.5 \times 10^{6} \mathrm{cpm}$ of $\left[{ }^{35} \mathrm{~S}\right]$ methionine-labeled cell extracts were used for each precipitation. Affinity-purified, rabbit anti-human TGase2 IgG-type antibodies (Dr. L. Fesus, Debrecen Medical School Apoptosis Research Foundation, Hungary) were used in the immunoprecipitations. After 3 washes with RIPA buffer, the immunoprecipitates were analyzed on a $10 \%$ SDS-polyacrylamide gel. The gel was fluorographed, dried and exposed.

\section{RESULTS}

\section{Presence of TGase 2 transcripts in human melanoma cell lines}

Total RNA isolated from different human melanoma cell lines was subjected to Northern-blot analysis with a $3.5-\mathrm{kb}$ human Tgase 2 cDNA probe. Autoradiography revealed the cognate, 3.7-kb hybridization signal (Fig. 1). Pronounced Tgase 2 expression was seen in the highly metastatic cell lines BLM and MV3 (lanes C, D), while for the weakly metastatic cell lines, only trace expression was detectable in IF6 (lane B), and no expression in 530 (lane A). To determine whether a corresponding expression pattern would occur in the xenograft tumors of these cell lines, we analyzed total RNA from xenografts (Fig. 2). The observed Tgase2 expression was highest in the BLM- and MV3-derived xenografts (lanes C, D), while no expression was detected in the 530 - and $1 \mathrm{~F} 6$-derived xenografts (lanes A, B).

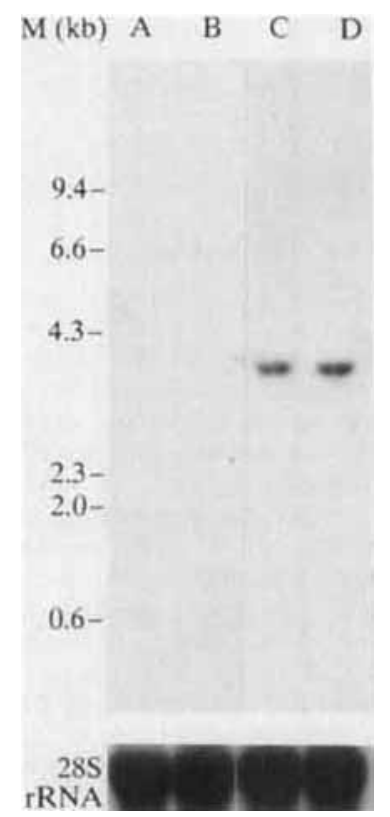

Figure 1 - Northern-blot analysis of human melanoma cell lines; $10 \mu \mathrm{g}$ of total RNA were loaded in each lane. Lane A, 530; lane B, 1 F 6 ; lane C, BLM; lane D, MV3. The blot was hybridized to radiolabeled 3.5-kb human TGase 2 cDNA. The MW marker was $\lambda$ DNA digested with restriction enzyme Hind111. Below: control hybridization, using a $28 \mathrm{~S}$ ribosomal probe.

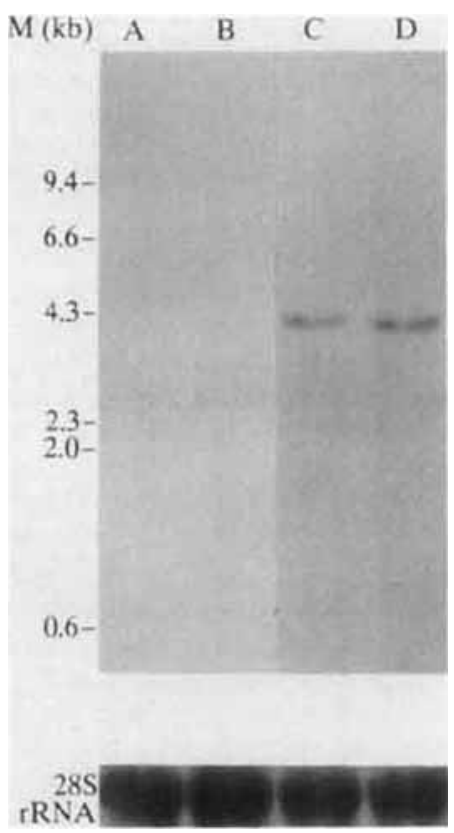

FIGURE 2 - Northern-blot analysis of melanoma xenografts in nude mice: $20 \mu \mathrm{g}$ of total RNA were loaded in each lane. Lane A 530; lane B, 1F6; lane C, BLM; lane D, MV3. The blot was hybridized to radiolabeled $3.5-\mathrm{kb}$ human TGase 2 cDNA. The MW marker was $\lambda$ DNA digested with Hind111. Below: control hybridization, using a $28 \mathrm{~S}$ ribosomal probe.

\section{TGase enzymatic activity in human melanoma cell lines}

For further characterization of the TGase 2 expression, the enzymatic activity was measured in cytoplasmic extracts prepared from the human melanoma cell lines with differing 


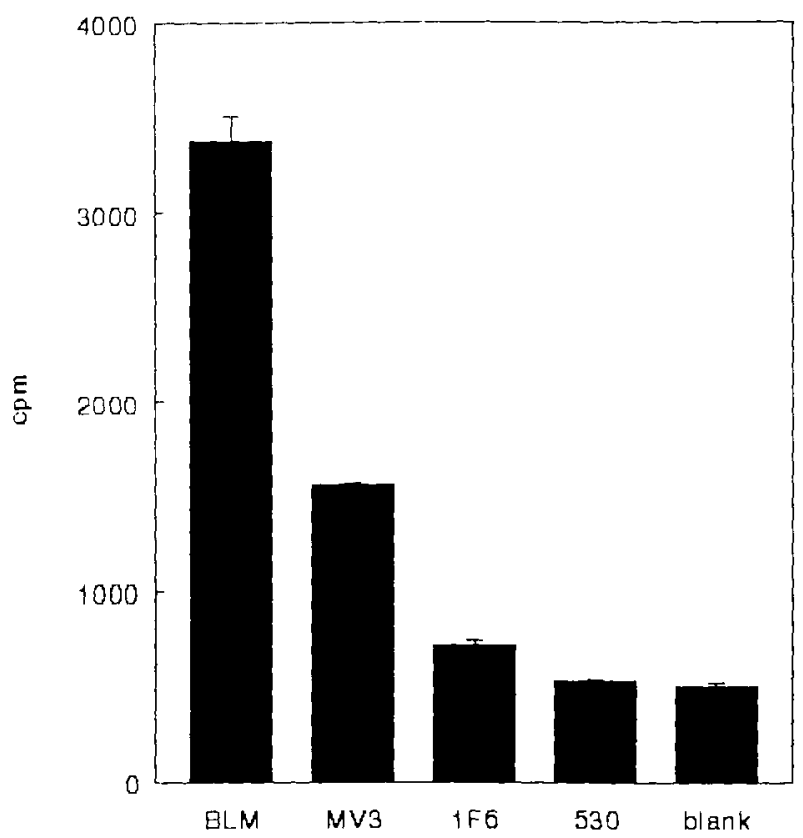

Figure 3 - Levels of TGase activity in the human melanoma cell lines BLM, MV3, 1F6 and 530. TGase activity was determined on the cell extracts as described in the text. The blank activity represents assays with BLM and MV3 extracts in the presence of $50 \mathrm{mM}$ EDTA. Data represent the mean values $\pm \mathrm{SE}$ from 3 experiments

metastatic behavior. The assay tested endogenous TGase activity acting on endogenous substrates. As shown in Figure 3, the TGase activity in the highly metastatic cell lines MV3 and BLM was significantly higher ( $p \leq 0.05$ using a 2-sample $t$-test) than in the weakly metastatic cell lines $1 \mathrm{~F} 6$ and 530 , of which only the former showed a low level of TGase activity. This result is in agreement with the differential expression of TGase 2 transcripts shown in Figure 1. Some control assays were performed in which purified guinea-pig TGase and/or cascine, a common TGase substrate, were included in the reaction mixtures (results not shown). These control assays make it clear that the observed TGase activity profile is likely to reflect the corresponding differential mRNA expression pattern and cannot be explained by significant differences in the amounts of substrate proteins or specific enzyme inhibitors.

For a preliminary identification of the TGase substrates in the human melanoma cell lines, $\left[{ }^{14} \mathrm{C}\right]$ methylamine incorporation into proteins of the cytoplasmic extracts was analyzed on a $12.5 \%$ SDS-polyacrylamide gel (Fig. 4). As expected from the enzyme assays, substrate-incorporated $\left[{ }^{14} \mathrm{C}\right]$ methylamine could be detected only in BLM and MV3 extracts (lanes $A$ and $C$, respectively). As a consequence of its calcium dependence (Greenberg et al., 1991), the TGase activity was completely inhibited in the BLM and MV3 extracts in the presence of 10 mM EDTA (lanes B, D). The autoradiogram shows preferential labelling of some selected substrates with a few typical differences between BLM and MV3.

Immunoprecipitation of TGase 2

To examine TGase2 protein expression in the human melanoma cell lines, we performed immunoprecipitations on $\left[{ }^{35}\right.$ S]methionine-labeled cell extracts with anti-human tissue TGase 2 antibodies. The immunoprecipitates obtained from the highly metastatic cell lines MV3 (lane B) and BLM (lane D), contain the expected $80-\mathrm{kDa}$ TGase2 protein (Fig. 5). Trace amounts of TGase 2 are detectable in the weakly

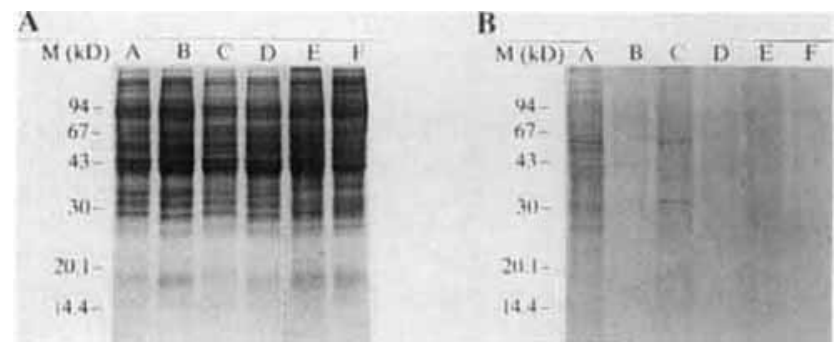

Figure 4 - Identification of TGase substrate(s) in several human melanoma cell lines; $30 \mu \mathrm{g}$ extract was loaded on each lane of a $12.5 \%$ SDS-polyacrylamide gel after $\left[{ }^{14} \mathrm{C}\right]$ methylamine incorporation as described in the text. Panel $(a)$ shows the Coomassie brilliant blue staining pattern and $(b)$ the corresponding autoradiograph. Lanes A and B, BLM; lanes C and D. MV3; lane E, 1F6; lane $\mathrm{F}, 530$. Lanes $\mathrm{B}$ and $\mathrm{D},\left[{ }^{14} \mathrm{C}\right]$ methylamine incorporation assay in the presence of $50 \mathrm{mM}$ EDTA.

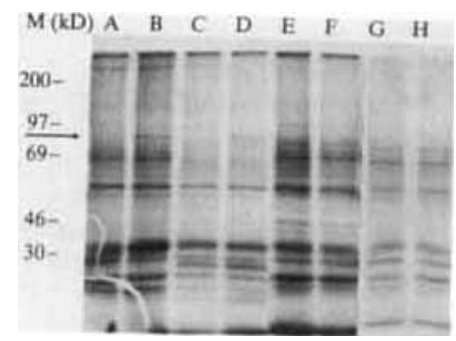

Figure 5 - Immunoprecipitation of TGase from several human melanoma cell lines; $2.5 \times 10^{6} \mathrm{cpm}$ of $\left[{ }^{35} \mathrm{~S}\right]$ methionine-labeled cell extracts were used for each precipitation, and the immunoprecipitates were analyzed on a $10 \%$ SDS-acrylamide gel. Lanes A and B, MV3; lanes C and D, BLM; lanes E and F, 530; lanes $G$ and $H$, 1F6. Lanes $A, C, E$, and $G$ were only incubated with protein A-Sepharose without addition of the antibody. The arrowhead indicates the position of human TGase?.

metastatic cell line 1F6 (lane H), while expression is absent in the 530 cell line (lane F). TGase 2 was specifically precipitated by the affinity-purified anti-human tissue TGase2 rabbit IgG antibody, since the $80-\mathrm{kDa}$ band is absent from control precipitations, in which only protein A-Sepharose was used with exclusion of the antibody (lanes A, C, E, G). In summary, all applied assays (Northern-blot analysis, enzyme activity tests, immunoprecipitations) yield corresponding results and support the conclusion that TGase 2 expression is elevated in metastasizing human melanoma cell lines.

\section{DISCUSSION}

Tissue-type transglutaminase (TGase2) is a ubiquitous enzyme, mainly because of its constitutive expression in smooth muscle and endothelium of the vessel wall, while it is inducible in most other cell types (Thomazy and Fesus, 1989). The enzymatic function of TGase 2 is well characterized and, among its biological functions, a participation in endocytosis (Davies et al., 1980), cellular adhesion (Gentile et al., 1992; Martinez et al., 1989) and apoptosis (Fesus et al., 1987; Alaoui et al., 1992) has been suggested. Additional experimental data are still required to characterize the suggested biological roles in detail.

Our results, as reported here, reveal a positive correlation between TGase 2 expression and metastatic behavior of human melanoma cell lines. We detected elevated expression of TGase mRNA only in the highly metastatic human melanoma cell lines MV3 and BLM. The differential expression of 
TGase 2 mRNA is also reflected at the protein and activity levels, as shown by immunoprecipitations and enzyme activity measurements.

The correlation between TGase 2 expression and neoplastic progression has been the subject of several studies dealing with animal tumor-cell lines. These studies revealed an inverse relation between metastatic behavior and expression of TGase2 (Beninati et al., 1993; Knight et al., 1990; Hand et al., 1988). It was anticipated that the presence of TGase 2 would be unfavorable for tumor progression. Such an assumption would be in accordance with its suggested promoting role in processes such as apoptosis and cell adhesion. Our data, however, do not support this assumption. Therefore, prudence is required, at the moment, in assigning functional relevance to TGase 2 expression in tumor progression studies without clear experimental evidence for such a role, be it beneficial or harmful.

While others have addressed the inverse relation between TGase 2 expression and tumor progression (Beninati et al., 1993; Knight et al., 1990; Hand et al., 1988), it is appropriate in the context of our data to look for an explanation of TGase2 expression in metastasizing cells. Several factors have been reported to be inducers of human TGase2, including retinoic acid (Suedhoff et al., 1990), transforming growth factor- $\beta$ (George et al., 1990), and interleukin-6 (Suto et al., 1993). Gain of interleukin-6 expression frequently accompanies acquisition of metastatic properties in human melanoma cells (Lu and Kerbel, 1993). In the investigated panel only the MV3 and BLM cell lines express interleukin-6 (data not shown). Alterna- tively, if the expression of TGase 2 in melanoma cells may be interpreted as a marker for apoptosis, this would mean that the highly metastatic cells can intrinsically monitor the accumulating mutations that should normally trigger this process, but somehow lack the ability to undergo programmed cell death.

What might be the functional significance of TGase 2 expression in metastasizing human melanoma cells? It could indicate that a deficient apoptosis program is triggered. As another speculation, one could imagine that the enzyme might catalyze cross-linking of extracellular-matrix-derived protein fragments to plasma membrane constituents and, thus, build up a more protective shell around the cell thus increasing its chances of survival in the circulation.

Whatever the explanation, the elevated TGase 2 expression observed in metastasizing melanoma cells can be used as an additional feature and experimental tool for characterizing changes occurring during neoplastic progression. It should be investigated whether the correlation between elevated TGase 2 expression and the progression stage of human tumor cell lines and tumors is a more general occurrence and also whether TGase 2 expression may serve diagnostic purposes. These topics will be the subject of future studies.

\section{ACKNOWLEDGEMENTS}

The authors are grateful to Dr. W.W. de Jong and Dr. P.J.T.A. Groenen for advice and discussion, and to Dr. W.G.J. Degen for his help in preparing the Figures.

\section{REFERENCES}

Alaoui, S.E., Mian, S., Lawry, J., Quash, G. and Griffin, M., Cell cycle kinetics, tissue transglutaminase and programmed cell death (apoptosis). FEBS Lett., 2, 174-178 (1992).

Auffray, C. and RougeON, F., Purification of mouse immunoglobulin heavy chain mRNAs from total myeloma tumor RNA. Europ. $J$. Biochem. 107, 303-314 (1980).

BANks-SCHLEGEL, S.P. and HARRIS, C.C.. Tissue-specific expression of keratin proteins in human esophageal and epidermal epithelium and their cultured keratinocytes. Exp. Cell Res., 146, 271-280 (1983).

Beninati, S., AbBrezzese, A. and Cardinali. M., Differences in the post-translational modification of proteins by polyamines between weakly and highly metastatic B16 melanoma cells. Int. J. Cancer, 53, 792-797 (1993).

BRADFORD, M., A rapid and sensitive method for the quantitation of microgram quantities of protein utilizing the principle of protein-dye binding. Anal. Biochem., 72, 248-254 (1976).

Bungay, J., Owen, R.A., Coutts, I.C. and Griffin, M., A role for transglutaminase in glucose-stimulated insulin release from the pancreatic beta cells Biochem. J., 335, 360-378 (1986).

Church, G.M. and GiLbert, W., Genomic sequencing. Proc. nat. Acad. Sci. (Wash.), 81, 1991-1995 (1984).

Davies, P.J.A., Davies, D.E., Levitzki, A., Maxfield, F.R., MilhaUd, P., WILlINGHAM, M.C. and PASTAN, I.H., Transglutaminase is essential in receptor mediated endocytosis of $\alpha_{2}$-macroglobulin and polypeptide hormones. Nature (Lond.), 283, 162-167 (1980).

Fesus, L., ThOMAZY, V. and Falus, A., Induction and activation of tissue transglutaminase during programmed cell death. FEBS Lett., 224, 104-108 (1987).

FOLK, J.E. and FINLAYSON, J.S., The $\epsilon$ - $(\gamma$-glutamyl $)$ lysine crosslink and the catalytic role of transglutaminases. Advanc. Prot. Chem., 31, 1-133 (1977).

Gentile, V., Saydak, M., Chiocca, E.A., Akande, O., BirckbickLER. P.J., LEe. K.N.. STEIN, J.P. and DAvies, P.J.A., Isolation and characterization of cDNA clones to mouse macrophage and human endothelial cell tissue transglutaminase. J. biol. Chem., 266, 478-483 (1991).

Gentile, V., Thomazy, V., Piacentini, M., Fesus, L. and Davies, P.J.A.. Expression of tissue transglutaminase in BALB/c-3T3 fibroblasts: effects on cellular morphology and adhesion. J. biol. Chem., 119, 463-474 (1992).
GeOrge, M.D., Vollberg, T.M., Floyd, E.E., STEIN, J.P. and HETTEN, A.M., Regulation of transglutaminase type II by transforming growth factor-beta 1 in normal and transformed human epidermal keratinocytes. J. biol. Chem., 265, 11098-11104 (1990).

Greenberg, C.S., BIRCKBICKLER, P.J. and RICE, R.H., Transglutaminases: multifunctional cross-linking enzymes that stabilize tissues. FASEB J., 5, 3071-3077 (1991).

HAND, D., Elliot, B.M. and GRIFFIN, M., Expression of the cytosolic and the particulate forms of transglutaminase during chemically induced rat liver carcinogenesis. Biochim. biophys. Acta, 970, 137-145 (1988).

IChinose, A.. Hendrickson, L.E., Fujikawa, K. and Davie, E.W., Amino acid sequence of the a subunit of human factor XIII. Biochemistry, 25, 6900-6906 (1986).

Kim, H.C., IDler, W.W., Kim, I.G., HaN, J.H., Chung, S.I. and STEINERT, P.M., The complete amino acid sequence of the human transglutaminase $\mathrm{K}$ enzyme deduced from the nucleic acid sequence of cDNA clones. J. biol. Chem., 266, 536-539 (1991).

KiM, I., MCBride, O.W., WANG, M., KiM, S., IDler, W.W. and STEINERT, P.M., Structure and organization of the human transglutaminase 1 gene. $J$. biol. Chem., 267, 7710 7717 (1992).

KNiGHT, C.R.L., ReES, R.C., ElliotT, B.M. and GRiffin, M., The existence of an inactive form of transglutaminase within metastasising tumours. Biochim. biophys. Acta, 1053, 13-20 (1990).

Lorand, L., Hsu, L.K., Siefring, G.E., JR. and RafFerty, N.S., Lens glutaminase and cataract formation. Proc. nat. Acad. Sci. (Wash.), 78, 1356-1360 (1981).

LU, C. and KERBEL, R.S., Interleukin-6 undergoes transition from paracrine growth inhibitor to autocrine stimulator during melanoma progression. J. cell. Biol., 120, 1281-1288 (1993).

Martinez, J., Rich, E. and Barsiglan, C., Transglutaminasemediated cross-linking of fibrinogen by human umbilical vein endothelial cells. J. biol. Chem., 264, 20502-20508 (1989).

McMaster, G.K. and Carmichael, G.G., Analysis of single and double-stranded nucleic acids on polyacrylamide and agarose gels using glyoxal and acridine orange. Proc. nat. Acad. Sci. (Wash.), 74, 4835-4838 (1977).

Suedhoff, T., Birckichler, P.J., Lee, K.N., Conway, E. and PATtERson, M.K., Differential expression of tissue transglutaminase in human erythroleukemia cells in response to retinoic acid. Cancer Res., 50, 7830-7834 (1990). 
Sung, L A Chien, S, L -S Lambert, K B Biss. S A., Bouhassira, E.E.. Naciel. R.L., SCHWarTz, R.S. and RybickI, A.C., Molecular cloning of human protein 4.2: a major component of the erythrocyte membrane. Proc. nat. Acad. Sci. (Wash.), 87, 955-959 (1990).

Suto, N., IKURA, K. and SASAKI, R., Expression induced by interleukin-6 of tissue-type transglutaminase in human hepatoblastoma HepG2 cells. J. biol. Chem., 268, 7469-7473 (1993).

THACHER, S.M. and RICE, R.H., Keratinocyte-specific transglutaminase of cultered human epidermal cells: relation to cross-linked envelope formation and terminal differentiation. Cell, 40, 685-695 (1985)
Thomazy, V. and Fesus, L., Differential expression of tissue transglutaminase in human cells. Cell Tiss. Res., 255, 215-224 (1989).

van MuUen, G.P.N., Cornelissen, L.M.A.H., JANSEn, C.P.J., FigDOR, C.G., JOHNSON, J.P., BroECKER, E.-B. and RUITER, D.J., Antigen expression of metastasizing and non-metastasizing melanoma cells xenografted to nude mice. Clin. exp. Metast., 9, 259-272 (1991a).

VAN MUiJen, G.P.N., JANSEN, C.P.J. CORNELISSEN, L.M.A.H., SMEeTS D.F.C.M., BECK. J.L.M. and RUITER, D.J., Establishment and characterization of human melanoma cell line (MV3) which is highly metastatic in nude mice. Int. J. Cancer, 48, 85-91 (1991b). 